\title{
ECOLOGICAL STUDIES ON THE EGYPTIAN MEALYBUG, ICERYA AEGYPTIACA (DOUGLAS) INFESTING THE ORNAMENTAL TREES, FICUS VIRENS AIT
}

\author{
EMAM, A. S. \\ Plant Protection Research Institute, ARC, Dokki, Giza, 12618 Egypt
}

(Manuscript received 27 July 2015)

\begin{abstract}
$\mathrm{S}$ easonal abundance of the Egyptian mealybug, Icerya aegyptiaca (Douglas) and the relation between the population activity, weather factors were studied during 2014 season on the ornamental trees Ficus virens Ait at Cairo and Giza Governorates. At El-Mireland Garden, Cairo Governorate data indicated that the total stages of the Egyptian mealybug have two activity generations; the first one with highest number occurred at the beginning of May while the $2^{\text {nd }}$ generation occurred in early October. On the other hand, the nymphs also have two activity

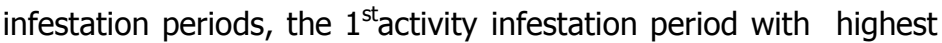
number in early May and the $2^{\text {nd }}$ infestation period was in early October. Also, the non-ovipositing females have two activity infestation periods, the $1^{\text {st }}$ one occurred in early June and the $2^{\text {nd }}$ was the mid of October. Finally, the ovipositing females start to appear in early of January and increased gradually to make one activity infestation period with highest number in the mid of June and the second infestation period in the mid of November. Statistical analysis shows that the simple correlation and simple regression between the maximum, minimum temperature and relative humidity with the monthly mean of total population, nymphal stages, ovipositing females and non-ovipositing females of I. aegyptiaca ranged between significant and highly significant at Cairo Governorate. The same trend was observed in El-Orman Garden, Giza Governorate. Generally the infestation of the Egyptian mealybug in El-Orman Garden, more than El- Mireland Garden, during successive season (2014).
\end{abstract}

\section{INTRODUCTION}

Icerya aegyptiaca (Douglas) is a highly polyphagous and widespread scale insect. According to the scale insect database, Scale Net (Ben-Dov et al. 2009), this pest feed on 123 species of plants belonging to 49 plant families. I. aegyptiaca has been given many common names, such as the breadfruit mealybug (Watson et al., 1995); most of the common names imply that the species is native to Egypt (e.g. Egyptian cottony cushion scale, or Egyptian fluted scale (Senthilkumar \& Barthakur 2005) and Egyptian mealy bug (Hall, 1922). It distributes in five regions in the world. They are Australasian; Afrotropical; Oriental; Palaearctic just in Japan (Kuwana, 1907 and Kawai, 1980) and Neotropical. It is recorded in Egypt in coccid list of Ezzat and Nada (1986). According to Habib and Taghavi (2007), I. aegyptiaca has the tendency 
to cause outbreaks in areas with little wind flow, such as the inner areas of bushes and can also cause cosmetic damage when its abundant white wax cover leaf surfaces. When its population densities are high, they may induce leaf drop symptoms (i.e. leaf yellowing, defoliation, reduced plant growth) and in some cases, dieback of the branches or of the entire plant due to feeding stress. Also they added that, the insect could often introduce plant pathogens such as viruses and fungi into a host. Akintola and Ande (2008) documented that unless there is a widespread attack in an area; the damage is usually overlooked or ascribed to other causes.

The aim of this work is studying the population fluctuation of the Egyptian mealybug, Icerya aegyptiaca (Douglas) (Hemiptera: Coccoidea: Monophlebidae) infesting ornamental trees, Ficus virens Ait. at Cairo and Giza Governorates.

\section{MATERIALS AND METHODS}

\section{Ecological studies:}

The ecological studies were carried out in El-Mireland Garden, Cairo Governorate and in El-Orman Garden, Giza Governorate, Egypt. Counting started from January to December during 2014 in the two governorates. Twenty infested Ficus virens trees, nearly of the same age and size were used for sampling. Twenty leaves were randomly taken biweekly intervals. methods of sampling adopted by Mangoud (2000). Twenty leaves were selected at random from all parts of the tree (east, west, north, south and central core). The samples were kept separately in polyethylene bags and transferred to the laboratory for counting by the aid of a stereomicroscope. Both surfaces of the leaf were inspected and the immature stages (first, second and third nymphal instars) and females (non-ovipositing and ovipositing ) were counted.

Generation is defined, as the time required for an insect to complete its life cycle, (i.e. from egg to egg). In the case of Margarodidae, eggs are oviposited in ovisac attached to the end of female shield until they hatch and crawl out. The only way to detect oviposition is by opening the female ovi-sac. Ovipositing females are defined as females that have their eggs in ovi-sac. The presence of ovipositing females (i. e. the transformation of adult females to ovipositing females) is considered under this study as presence of the egg stage. This phenomenon was used to determine the end of each generation and the beginning of the next one. The absolute number of each stage per sample per count can vary dramatically from one count to another. The difference between counts can be contributed to actual change in insect's population as well as sampling errors.

\section{Weather factors:}

Effects of weather factors on the population of $I$. aegyptiaca included daymaximum temperature (D. Max. T.), day minimum temperature (D. Min. T.) and daily mean relative humidity (D.M. R.H.) were studies. Records of the weather factors of 
Cairo and Giza Governorates were obtained from the Central Laboratory for Agriculture Meteorology, Agricultural Research Center, Ministry of Agriculture. The daily records of each weather factor were grouped into biweekly averages according to the sampling dates. These averages were assumed to represent the field experimental records at sampling times.

\section{Statistical analysis:}

The simple correlation ( $r$ ) and regression coefficient value (b) were adopted to clarify the change in population due to change in each of weather factors and the mean values compared with the least significant differences as well as, SAS program (SAS Institute 1988).

\section{RESULTS AND DISCUSSION}

\section{Population fluctuations of the different stages of $I$. aegyptiaca on $F$. virens trees during season, 2014:}

It is well-known fact that precise knowledge of appropriate date of the Egyptian mealybug, I. aegyptiaca activity from the one hand and number and duration of annual field generations from the other is considered the fundamental basic information for Integrated Pest Management programs. This work was dedicated to monitor the changes in the population density of the I. aegyptiaca, which occurs on the

F. virens trees. The first, by integrating the fluctuations in the seasonal abundance curve expressed as number of half monthly count on F. virens trees at El-Mireland Garden, Cairo Governorate and in El-Orman Garden, Giza Governorate.

\section{A.) The population At El-Mireland Garden:}

Data tabulated in Table (1) and graphically illustrated in Fig. (1) show the population fluctuations of the different stages of I. aegyptiaca at El-Mireland Garden, indicated by half monthly count of the different stages i.e. nymphs, ovipositing and non-ovipositing females during 2014year. As shown in Table (1) and Fig. (1) the population fluctuations of the different stages significantly different all over the year, the fluctuations in the population density nymphs throughout (January-December). The integration of the seasonal abundance curve revealed the presence of two peaks, which represent two overlapping generations. The following are a brief description of these generations:

\section{- Total stages:}

The total stages start to appear as early of January and increased gradually to make first generation with highest number on beginning of May with average mean number 3394 individuals when maximum temperature was $31.2^{\circ} \mathrm{C}$ and minimum temperature was $19.4^{\circ} \mathrm{C}$ also the relative humidity was $49 \%$; the population density was high and appeared the most economically important, after that then the infestation with total stages decreased to mid-August (Table 1 and Fig. 1). 
The infestation with total stages increased beginning of early September and increased gradually to make the second generation on beginning of October with average mean number 2402 individuals when maximum temperature was $31.9^{\circ} \mathrm{C}$ and minimum temperature was $22.7^{\circ} \mathrm{C}$ also the relative humidity was $56 \%$ and decreased again till the end of the year. This generation period demonstrated the moderate number as compared with the first generation of total stages.

Table 1. Half-monthly counts of different stages of the Egyptian mealybug, Icerya aegyptiaca (Douglas) infesting Ficus virens Ait. trees in El-Mireland Garden, during 2014 season.

\begin{tabular}{|c|c|c|c|c|c|c|c|}
\hline \multirow[b]{2}{*}{ Date } & \multicolumn{3}{|c|}{ Average no. of individual } & \multirow[b]{2}{*}{ Total } & \multicolumn{3}{|c|}{ Weather factors } \\
\hline & Nymphs & $\begin{array}{c}\text { Non- } \\
\text { ovipositing } \\
\text { Females }\end{array}$ & $\begin{array}{c}\text { Ovipositing } \\
\text { females }\end{array}$ & & $\begin{array}{l}\text { Max. } \\
\text { Temp }\end{array}$ & $\begin{array}{l}\text { Min. } \\
\text { Temp }\end{array}$ & $\mathrm{RH} \%$ \\
\hline $01 / 01 / 2014$ & 245 & 98 & 89 & 432 & 16.9 & 8.1 & 81 \\
\hline $15 / 01 / 2014$ & 325 & 101 & 66 & 492 & 19.7 & 9.5 & 73 \\
\hline $01 / 02 / 2014$ & 397 & 147 & 78 & 622 & 20.1 & 9.9 & 70 \\
\hline $15 / 02 / 2014$ & 422 & 150 & 91 & 663 & 22.6 & 12.2 & 72 \\
\hline $01 / 03 / 2014$ & 591 & 245 & 115 & 951 & 27.0 & 12.8 & 69 \\
\hline $15 / 03 / 2014$ & 688 & 267 & 145 & 1100 & 20.6 & 10.4 & 65 \\
\hline $01 / 04 / 2014$ & 945 & 297 & 198 & 1440 & 22.5 & 12.5 & 57 \\
\hline $15 / 04 / 2014$ & 1758 & 318 & 211 & 2287 & 29.8 & 15.6 & 48 \\
\hline $01 / 05 / 2014$ & 2658 & 449 & 287 & 3394 & 31.2 & 19.4 & 49 \\
\hline $15 / 05 / 2014$ & 2217 & 530 & 341 & 3088 & 32.7 & 15.4 & 46 \\
\hline $01 / 06 / 2014$ & 1988 & 566 & 374 & 2928 & 29.1 & 17.6 & 47 \\
\hline $15 / 06 / 2014$ & 1649 & 325 & 395 & 2369 & 34.9 & 18.8 & 44 \\
\hline $01 / 07 / 2014$ & 987 & 289 & 275 & 1551 & 32.8 & 21.0 & 56 \\
\hline $15 / 07 / 2014$ & 847 & 275 & 201 & 1323 & 33.7 & 21.9 & 59 \\
\hline $01 / 08 / 2014$ & 855 & 261 & 179 & 1295 & 35.4 & 22.1 & 53 \\
\hline $15 / 08 / 2014$ & 911 & 187 & 181 & 1279 & 36.8 & 23.8 & 54 \\
\hline $01 / 09 / 2014$ & 997 & 194 & 191 & 1382 & 34.1 & 22.7 & 53 \\
\hline $15 / 09 / 2014$ & 1459 & 214 & 205 & 1878 & 32.7 & 20.9 & 53 \\
\hline $01 / 10 / 2014$ & 1878 & 311 & 213 & 2402 & 31.9 & 22.7 & 56 \\
\hline $15 / 10 / 2014$ & 917 & 378 & 247 & 1542 & 28.5 & 15.5 & 57 \\
\hline $01 / 11 / 2014$ & 847 & 360 & 251 & 1458 & 26.9 & 14.1 & 56 \\
\hline $15 / 11 / 2014$ & 714 & 315 & 278 & 1307 & 27.8 & 12.9 & 63 \\
\hline $01 / 12 / 2014$ & 498 & 233 & 205 & 936 & 22.1 & 10.9 & 69 \\
\hline $15 / 12 / 2014$ & 359 & 124 & 157 & 640 & 18.7 & 9.8 & 78 \\
\hline Total & 25152 & 6634 & 4973 & 36759 & - & - & - \\
\hline Mean & 1048.0 & 276.4 & 207.2 & 1531.6 & - & - & - \\
\hline
\end{tabular}





Fig. 1. Half-monthly counts of different stages of the Egyptian mealybug, Icerya aegyptiaca (Douglas) infesting Ficus virens Ait. trees in El-Mireland Garden, during 2014 season. 
Statistical analysis in Table (2) in 2014 year show that the simple correlation between the maximum, minimum temperature and relative humidity on the monthly mean of total population of $I$. aegyptiaca were highly significant and significant $(r=$ $0.60766,0.52116$ and -0.78605$)$, respectively. In addition, results in Table (2), show that the simple regression of the maximum, minimum temperature and relative humidity on the monthly mean of total population of $I$. aegyptiaca were highly significant and significant $(b=3.59,2.86 a n d-5.96)$, respectively.

\section{-Nymphal stages:}

The nymphs start to appear as early of January and increased gradually to make one activity infestation period with highest number at the beginning of May with average mean number 2658 individuals when maximum temperature was $31.2^{\circ} \mathrm{C}$ and minimum temperature was $19.4^{\circ} \mathrm{C}$ also the relative humidity was $49 \%$; the population density was high and appeared the most economically important, after that then the infestation with nymphs decreased to Mid-July Table (1).

The infestation with nymphs increased at the beginning of early August and increased gradually to make the second infestation period at the beginning of October with average mean number 1878 individuals when maximum temperature was $31.9^{\circ} \mathrm{C}$ and minimum temperature was $22.7^{\circ} \mathrm{C}$ also the relative humidity was $56 \%$ and decreased again till the end of the year. This infestation period demonstrated the moderate number as compared with the first infestation period of nymphs.

Table 2. Simple correlation and regression values between the weather factors and biweekly mean No. of the different stages of the Egyptian mealybug, Icerya aegyptiaca (Douglas) infesting Ficus virens Ait. trees in El-Mireland Garden during 2014 season.

\begin{tabular}{|c|c|c|c|c|c|}
\hline \multicolumn{2}{|c|}{ Variable } & Simple correlation " $r$ " & Probability "P" & Regression & Probability "P" \\
\hline \multirow{3}{*}{$\sum_{\substack{\frac{n}{0} \\
\sum}}$} & Max. Temp & 0.60101 & 0.0019 & 3.53 & 0.0019 \\
\hline & Min. Temp. & 0.53853 & 0.0066 & 3.00 & 0.0066 \\
\hline & R.H. \% & -0.75773 & 0.0001 & -5.45 & 0.0001 \\
\hline \multirow{3}{*}{ 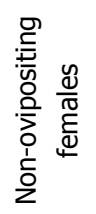 } & Max. Temp & 0.45497 & 0.0255 & 2.40 & 0.0255 \\
\hline & Min. Temp. & 0.31091 & 0.1392 & 1.53 & 0.1392 \\
\hline & R.H. \% & -0.75026 & 0.0001 & -5.32 & 0.0001 \\
\hline \multirow{3}{*}{ 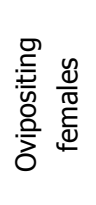 } & Max. Temp & 0.59248 & 0.0023 & 3.45 & 0.0023 \\
\hline & Min. Temp. & 0.44631 & 0.0288 & 2.34 & 0.0288 \\
\hline & R.H. \% & -0.68996 & 0.0002 & -4.47 & 0.0002 \\
\hline \multirow{3}{*}{$\begin{array}{l}\bar{\pi} \\
0 \\
\qquad\end{array}$} & Max. Temp & 0.60766 & 0.0016 & 3.59 & 0.0016 \\
\hline & Min. Temp. & 0.52116 & 0.0090 & 2.86 & 0.0090 \\
\hline & R.H. \% & -0.78605 & 0.0001 & -5.96 & 0.0001 \\
\hline
\end{tabular}


Results in Table (2) indicated that the simple correlation between the maximum, minimum temperature and relative humidity on the monthly mean of total population of $I$. aegyptiaca were highly significant and significant $(r=0.60101,0.53853$ and 0.75773), respectively. In addition, results in Table (2), show that the simple regression of the maximum, minimum temperature and relative humidity on the monthly mean of total population of $I$. aegyptiaca were highly significant and significant $(b=3.53,3.00$ and -5.45$)$, respectively.

Osman (2005) reported 2-4 and 3-4 annual activity peaks for Icerya seychellarum nymphs and females, respectively, occurred on mulberry (Morus spp.) at Giza and Qualyobia Governorates, Egypt, whereas total population had 2 peaks annually. Three and four successive overlapping generations of $I$. seychellarum were reported at Qualyobia and Giza Governorates, respectively.

\section{-Non-ovipositing females:}

The non-ovipositing females start to appear as early of January and increased gradually to make one activity infestation period with highest number on beginning of June with average mean number 566 individuals when maximum temperature was $29.1^{\circ} \mathrm{C}$ and minimum temperature was $17.6^{\circ} \mathrm{C}$ also the relative humidity was $47 \%$; the population density was high and appeared the most economically important, after that then the infestation with non-ovipositing decreased to mid-August (Table, 1).

The infestation with non-ovipositing increased beginning of early September and increased gradually to make the second infestation period in mid-October with average mean number 378 individuals when maximum temperature was $28.5^{\circ} \mathrm{C}$ and minimum temperature was $15.5^{\circ} \mathrm{C}$ also the relative humidity was $57 \%$ and decreased again till the end of the year. This infestation period demonstrated the moderate number as compared with the first infestation period non-ovipositing females.

Data in Table (2) show that the simple correlation between the maximum and the monthly mean of total population of $I$. aegyptiaca was significant $(r=0.45497)$, while was non-significant between minimum temperature $(r=0.31091)$, whereas, was highly significant between relative humidity $(r=-0.75026)$. The same trend was obtained in case the simple regression $(b=2.40,1.53$ and -5.32$)$, respectively.

The obtained results are agreement with those obtained by Hill and Newbery (1980) who mentioned that Icerya seychellarumbreeds continuously and has a generation time of 2-3 months on mangrove, Avicennia marine (Forsk) at Aldabra atoll, in Seychelles. 


\section{-Ovipositing females:}

The ovipositing females start to appear as early of January and increased gradually to make one activity infestation period with highest number on mid-June with average mean number 395 individuals when maximum temperature was $34.9^{\circ} \mathrm{C}$ and minimum temperature was $18.8^{\circ} \mathrm{C}$ also the relative humidity was $44 \%$; the population density was high and appeared the most economically important, after that then the infestation with ovipositing decreased to mid-August Table (1).

The infestation with ovipositing increased beginning of early- September and increased gradually to make the second infestation period on mid-November with average mean number 278 individuals when maximum temperature was $27.8^{\circ} \mathrm{C}$ and minimum temperature was $12.9^{\circ} \mathrm{C}$ also the relative humidity was $63 \%$ and decreased again till the end of the year. This infestation period demonstrated the moderate number as compared with the first infestation period ovipositing females.

Statistical analysis in Table (2) show that the simple correlation between the maximum, minimum temperature and relative humidity were significant or highlysignificant on the monthly mean of total population of $I$. aegyptiaca $(r=0.59248$, 0.44631 and -0.68996$)$, respectively. The same tend was observed in Table (2), in case the simple regression $(b=3.45,2.34$ and -4.47$)$, respectively.

Ali (1980) recorded three overlapping generations of Icerya seychellarumon on palm tree Latania commersonii annually at Suez district, Egypt.

\section{B-) The population At El-Orman Garden:}

Data tabulated in Table (3) and Fig. (2) show the population fluctuations of the different stages of $I$. aegyptiaca at El-Orman Garden, Giza Governorate as indicated by half monthly count of the different stages i.e. nymphs, ovipositing and non-ovipositing females during 2014 year.

As shown in Table (3) and Fig. (2) population fluctuations of the different stages significantly different all over the year, the fluctuations in the population density nymphs throughout complete year (2014) (January-December). The integration of the seasonal abundance curve revealed the presence of two peaks, which represent two overlapping generations. The following are a brief description of these generations:

\section{-Total stages:}

Results in Table ( 3 ) and Fig. ( 2) indicated that the total stages of $I$. aegyptiaca start to appear as early of January and increased gradually to make first generation with highest number on mid-May with average mean number 5028 individuals when maximum temperature was $35.6^{\circ} \mathrm{C}$ and minimum temperature was $16.3^{\circ} \mathrm{C}$ also the relative humidity was $50 \%$; after that the infestation with total stages decreased to early- September. The infestation with total stages increased beginning 
Table 3. Half-monthly counts of different stages of the Egyptian mealybug, Icerya aegyptiaca (Douglas) infesting Ficus virens Ait. trees in El-Orman Garden, during 2014 season.

\begin{tabular}{|c|c|c|c|c|c|c|c|}
\hline \multirow[b]{2}{*}{ Date } & \multicolumn{3}{|c|}{ Average no. of individual } & \multirow[b]{2}{*}{ Total } & \multicolumn{3}{|c|}{ Weather factors } \\
\hline & Nymphs & $\begin{array}{c}\text { Non- } \\
\text { ovipositing } \\
\text { Females }\end{array}$ & $\begin{array}{c}\text { Ovipositing } \\
\text { females }\end{array}$ & & $\begin{array}{l}\text { Max. } \\
\text { Temp }\end{array}$ & $\begin{array}{l}\text { Min. } \\
\text { Temp }\end{array}$ & $\mathrm{RH} \%$ \\
\hline $01 / 01 / 2014$ & 389 & 154 & 109 & 652 & 19.2 & 9.8 & 87 \\
\hline $15 / 01 / 2014$ & 417 & 187 & 127 & 731 & 21.4 & 10.4 & 76 \\
\hline $01 / 02 / 2014$ & 478 & 204 & 145 & 827 & 22.7 & 11.8 & 75 \\
\hline $15 / 02 / 2014$ & 548 & 233 & 157 & 938 & 27.9 & 13.1 & 74 \\
\hline $01 / 03 / 2014$ & 615 & 297 & 163 & 1075 & 29.2 & 13.3 & 72 \\
\hline $15 / 03 / 2014$ & 792 & 318 & 196 & 1306 & 25.9 & 11.8 & 69 \\
\hline $01 / 04 / 2014$ & 1347 & 416 & 217 & 1980 & 24.7 & 13.2 & 61 \\
\hline $15 / 04 / 2014$ & 3048 & 527 & 298 & 3873 & 31.9 & 16.1 & 55 \\
\hline $01 / 05 / 2014$ & 3558 & 658 & 301 & 4517 & 34 & 20.2 & 56 \\
\hline $15 / 05 / 2014$ & 3816 & 819 & 393 & 5028 & 35.6 & 16.3 & 50 \\
\hline $01 / 06 / 2014$ & 3247 & 917 & 422 & 4586 & 35 & 18.9 & 50 \\
\hline $15 / 06 / 2014$ & 3018 & 824 & 514 & 4356 & 36.1 & 20.2 & 54 \\
\hline $01 / 07 / 2014$ & 2145 & 651 & 438 & 3234 & 35.3 & 23.2 & 60 \\
\hline $15 / 07 / 2014$ & 1985 & 497 & 414 & 2896 & 34.5 & 23 & 61 \\
\hline $01 / 08 / 2014$ & 1644 & 405 & 388 & 2437 & 37.2 & 23.4 & 57 \\
\hline $15 / 08 / 2014$ & 1319 & 358 & 264 & 1941 & 37.3 & 24.2 & 58 \\
\hline $01 / 09 / 2014$ & 1118 & 526 & 208 & 1852 & 35.3 & 23.9 & 56 \\
\hline $15 / 09 / 2014$ & 1619 & 611 & 307 & 2537 & 34.5 & 21.7 & 56 \\
\hline $01 / 10 / 2014$ & 1964 & 688 & 389 & 3041 & 32.8 & 23.7 & 57 \\
\hline $15 / 10 / 2014$ & 1422 & 711 & 405 & 2538 & 30.7 & 16.3 & 58 \\
\hline $01 / 11 / 2014$ & 1215 & 655 & 419 & 2289 & 29.3 & 15 & 59 \\
\hline $15 / 11 / 2014$ & 918 & 419 & 422 & 1759 & 28.4 & 14.3 & 64 \\
\hline $01 / 12 / 2014$ & 745 & 317 & 317 & 1379 & 24.3 & 12.6 & 75 \\
\hline $15 / 12 / 2014$ & 541 & 244 & 207 & 992 & 22.1 & 10.8 & 79 \\
\hline Total & 37908 & 11636 & 7220 & 56764 & - & - & - \\
\hline Mean & 1579.5 & 484.8 & 300.8 & 2365.2 & - & - & - \\
\hline
\end{tabular}





Fig. 2. Half-monthly counts of different stages of the Egyptian mealybug, Icerya aegyptiaca (Douglas) infesting the Ficus virens Ait. trees in El-Orman Garde during 2014 season. 
of mid- September and increased gradually to make the second generation on earlyOctober with average mean number 3041 individuals when maximum temperature was $32.8^{\circ} \mathrm{C}$ and minimum temperature was $19.7^{\circ} \mathrm{C}$ also the relative humidity was $57 \%$ and decreased again till the end of the year. This generation period demonstrated the moderate number as compared with the first generation of total stages.

Statistical analysis in Table (4) show that the simple correlation between the maximum, minimum temperature and relative humidity on the monthly mean of total population of $I$. aegyptiaca were highly significant and significant $(r=0.72637$, 0.53927 and -0.7948), respectively. In addition, the simple regression of the maximum, minimum temperature and relative humidity on the monthly mean of total population of $I$. aegyptiaca were highly significant and significant $(b=4.96,3.00$ and $-6.14)$, respectively.

Mangoud (2000) mentioned that Icerya seychellarumhas 2-3 population peaks/year on apple trees on late-June, late-October and mid-December in Egypt.

\section{-Nymphal stages:}

The nymphs start to appear as early of January and increased gradually to make

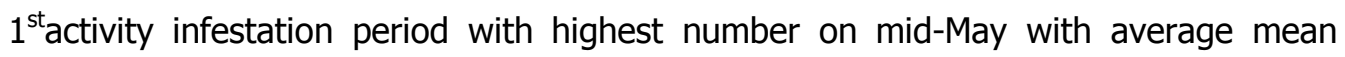
number 3816 individuals when maximum temperature was $35.6^{\circ} \mathrm{C}$ and minimum temperature was $16.3^{\circ} \mathrm{C}$ also the relative humidity was $50 \%$; the population density was high and appeared the most economically important, after that then the infestation with nymphs decreased to early-September Table (3). The infestation with nymphs increased again on mid-September and increased gradually to make the second infestation period on early October with average mean number 1964 individuals when maximum temperature was $32.8^{\circ} \mathrm{C}$ and minimum temperature was $23.7^{\circ} \mathrm{C}$ also the relative humidity was $57 \%$ and decreased again till the end of the year. This infestation period demonstrated the moderate number as compared with the first infestation period of nymphs. 
Table 4. Simple correlation and regression values between the weather factors and biweekly mean No. of the different stages of the Egyptian mealybug, Icerya aegyptiaca (Douglas) infesting Ficus virens Ait. trees in El-Orman Garden during 2014 season.

\begin{tabular}{|c|c|c|c|c|c|}
\hline \multicolumn{2}{|c|}{ Variable } & Simple correlation " $r$ " & Probability "P" & Regression & Probability "P" \\
\hline \multirow{3}{*}{$\frac{\text { con }}{\stackrel{\text { हn }}{z}}$} & Max. Temp & 0.69393 & 0.0002 & 4.52 & 0.0002 \\
\hline & Min. Temp. & 0.49301 & 0.0144 & 2.66 & 0.0144 \\
\hline & R.H. \% & -0.74430 & 0.0001 & -5.23 & 0.0001 \\
\hline \multirow{3}{*}{ 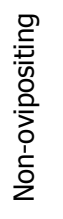 } & Max. Temp & 0.70547 & 0.0001 & 4.67 & 0.0001 \\
\hline & Min. Temp. & 0.55975 & 0.0045 & 3.17 & 0.0045 \\
\hline & R.H. \% & -0.83674 & 0.0001 & -7.17 & 0.0001 \\
\hline \multirow{3}{*}{ 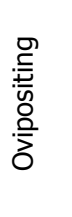 } & Max. Temp & 0.65931 & 0.0005 & 4.11 & 0.0005 \\
\hline & Min. Temp. & 0.62043 & 0.0012 & 3.71 & 0.0012 \\
\hline & R.H. \% & -0.73418 & 0.0001 & -5.07 & 0.0001 \\
\hline \multirow{3}{*}{$\begin{array}{l}\overline{\mathbb{\pi}} \\
\text { O }\end{array}$} & Max. Temp & 0.72637 & 0.0001 & 4.96 & 0.0001 \\
\hline & Min. Temp. & 0.53927 & 0.0065 & 3.00 & 0.0065 \\
\hline & R.H. \% & -0.79479 & 0.0001 & -6.14 & 0.0001 \\
\hline
\end{tabular}

Results in Table (4) indicated that the simple correlation between the maximum, minimum temperature and relative humidity on the monthly mean of total population of $I$. aegyptiaca were highly significant and significant $(r=0.69393$, 0.49301 and -0.7443 ), respectively. In addition, results in Table (4), show that the simple regression of the maximum, minimum temperature and relative humidity on the monthly mean of total population of $I$. aegyptiaca were highly significant and significant $(b=4.52,2.66$ and -5.23$)$, respectively.

\section{-Non-ovipositing females:}

The non-ovipositing females start to appear as early of January and

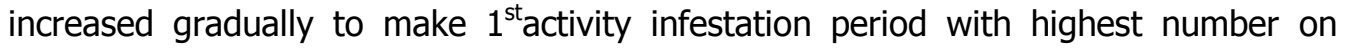
early-June with average mean number 917 individuals when maximum temperature was $35.0^{\circ} \mathrm{C}$ and minimum temperature was $18.9^{\circ} \mathrm{C}$ also the relative humidity was $50.0 \%$, after that then the infestation with non-ovipositing decreased to mid-August Table (3).The infestation increased again beginning of mid-August and increased 
gradually to make the second infestation period on mid-October with average mean number 711 individuals when maximum temperature was $30.7^{\circ} \mathrm{C}$ and minimum temperature was $16.3^{\circ} \mathrm{C}$ also the relative humidity was $58.0 \%$ and decreased again till the end of the year. This infestation period demonstrated the moderate number as compared with the first infestation period non-ovipositing females.

Data in Table (4) show that the simple correlation between the maximum, minimum temperature and relative humidity and the monthly mean of non-ovipositing females of $I$. aegyptiaca were highly or significant $(r=0.70547,0.55975$ and $0.8367)$. The same trend was obtained in case the simple regression $(b=4.67,3.17$ and -7.17), respectively.

\section{-Ovipositing females:}

The ovipositing females start to appear as early of January and increased


average mean number 514 individuals when maximum temperature was $36.1^{\circ} \mathrm{C}$ and minimum temperature was $20.2^{\circ} \mathrm{C}$ also the relative humidity was $54 \%$; the population density was high and appeared the most economically important, after that then the infestation with ovipositing decreased to early-September Table (3).The infestation increased again beginning of mid-September and increased gradually to make the second infestation period on mid-November with average mean number 422 individuals when maximum temperature was $28.4^{\circ} \mathrm{C}$ and minimum temperature was $14.3^{\circ} \mathrm{C}$ also the relative humidity was $64 \%$ and decreased again till the end of the year. This infestation period demonstrated the moderate number as compared with the first infestation period ovipositing females. Statistical analysis in Table (4) indicated that the simple correlation between the maximum, minimum temperature and relative humidity were significant or highly-significant on the monthly mean of ovipositing females of $I$. aegyptiaca $(r=0.65931,0.62043$ and -0.7342$)$, respectively. The same tend was observed in Table (4), in case the simple regression $(b=4.11$, 3.71 and -5.07$)$, respectively.

The obtained results are agreement with those obtained by, Tawfik and Mohammad (2001) found that Icerya seychellarumhad only two population peaks/year on Morusalba. Also, El-Borollosyet al. (1990) in Egypt, recorded three annual generations of Icerya seychellarum on the ornamental palm, Cycus revolute. 


\section{REFERENCES}

1. Akintola, A.J. and A. T. Ande. 2008. First record of Phenacoccus solenopsis Tinsley (Hemiptera: Pseudococcidae) on Hibiscus rosa-sinensis in Nigeria. Med. Agric. J., 3(1):13.

2. Ali, A. G. 1980. Studies on palm tree insects belongs to super family Coccoidea in Egypt. Ph.D. Thesis, Fac. Agric., Al-Azhar Univ., Cairo, Egypt., 79: 255- 262.

3. Ben-Dov, Y.; D. R. Miller and G. A. B. Gibson. 2009. Scale Net: a database of the scale insects of the world [database on the internet.] [Cited 1 Feb 2009.]Available from URL: http://www.sel.barc. usda.gov/scale net/scalenet.htm

4. El-Borollosy, F. M.; M. M. Elbolok; A. I. Ezz and S. M. Assem. 1990. Ecological studies (in Egypt) on the ornamental palm mealybug, Icerya seychellarum (Westwood) (Margarodidae, Homoptera) on a Cycusrevoluta Thumb (Cycadaceae): Bulletin de la Societe Entomologique d'Egypte, 69: 257-265.

5. Ezzat, Y.M. and S. M. A. Nada. 1986. List of super family Coccoidea as known toexist in Egypt.Ball. Lab. Eutomd. Agr." Filippo Silvestri", 43: 85-90.

6. Habib, A. and A. Taghavi. 2007. Description and seasonal abundance of the tea mealybug, Pseudococcidae viburni (Affinis). Journal of Entomology 4 (6): 474-478.

7. Hall, W.J. 1922. Observations on the Coccidae of Egypt. Bulletin, Ministry of Agriculture, Egypt. Tech. and Scientific Service 22, 1-54.

8. Hill, M.G. and D. Newbery. 1980. The distribution and abundance of the coccid Icerya seychellarum Westw. on Aldabra Atoll. Ecol. Entomol., 5: 115-122 .

9. Kawai, S. 1980. Scale insects of Japan in colors. (in Japanese). National Agricultural Education, Tokyo, $455 \mathrm{pp}$.

10. Kuwana, S.I. 1907. Coccidae of Japan, I. A. Synoptically list of Coccidae of Japan with description of thirteen new species. Bull. of the Imperial Central Agric. Exper. Stat., Japan I: $177-212$.

11. Mangoud, A. A. H. 2000. Integrated pest management of apple trees. Ph. D. Thesis, fac. of agriculture, Cairo Univ. Giza, Egypt, 225 pp.

12. Osman, E.A. 2005. Studies on some homopterous insect pests infesting mulberry trees in relation with Bombyx mori L. (Bombycidae: Lepidoptera) Silk production. Ph.D Thesis. Fac. Agric., Cairo Univ. Egypt. 
13. SAS Institute. 1988. SAS/STAT User`s Guide, Ver. 6.03. SAS Institute Inc., Cary, North Carolina.

14. Senthilkumar, N. and N. D. Barthakur. 2005. A record of Egyptian fluted scale, Icerya aegyptiaca (Douglas) on teak in Assam. Insect Environ. 11, 31-32.

15. Tawfik, M.H. and Z. K. Mohammad. 2001. Ecological studies of two scale insects (Hemiptera :Coccoidea) on Morus alba in Egypt. Bollettino di Zoologia Agrariae di Bachicoltura (Milano), 33(3): 267-273.

16. Watson, G.W.; P. A. C. Ooi and D. J. Girling. 1995. Insects on Plants in the Maldives and Their Management. Intern. Institute of Entomol., London. 65: 564 - 576. 
Icerya aegyptiaca ( Douglas ) راسات بيئية على حشرة البق الدقيقي المصري Ficus virens Ait. التى تصيب أشجار الزينة

$$
\begin{aligned}
& \text { أثـــرف صــلاح إمــام } \\
& \text { معهز بحوث وقاية النباتات - مركز البحوث الزرراعية- الدقي - الجيزة - مصر }
\end{aligned}
$$

نم دراسة التعداد الموسمي لحشرة البق الدقيقي المصري Icerya aegyptiaca وكذلك تأثير التغير في الظروف المناخية من حرارة ورطوبة علي الأطوار المختلفة للحشرة خلال موسم الدراسة

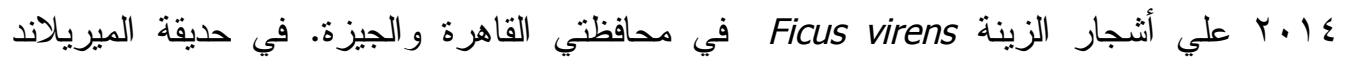
بمحافظة القاهرة وحديقة الأورمان بمحافظة الجيزة . بالنسبة لحديقة الميريلاند بمحافظة القاهرة فقد وجد أن الأعداد الكلية لهذه الحشرة لها قمتين



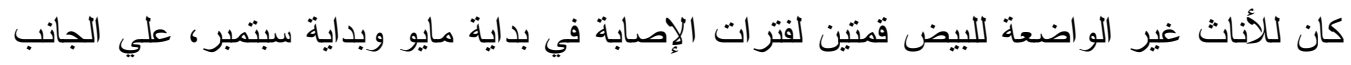

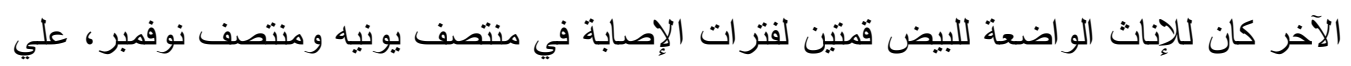
الترتيب. أثنت التحليل الأحصائي أن هنالك علاقة معنوية بين كل من التعداد الكلي و الحوريات و الإناث الكاملة سو اء الواضعة للبيض وغير الواضعة للبيض و بين الظروف المناخية من حرارة ورطوبة. أما بالنسبة لتعداد البق الدقيقي المصري في محافظة الجيزة (حديقة الأورمان) فقد تم

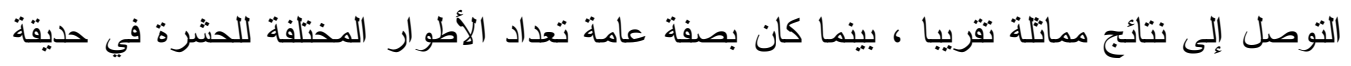

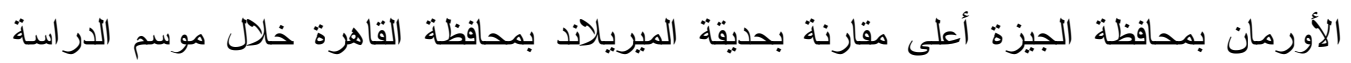

